\title{
Inactivating BRAF Gene Mutation
}

National Cancer Institute

\section{Source}

National Cancer Institute. Inactivating BRAF Gene Mutation. NCI Thesaurus. Code C156046.

A change in the nucleotide sequence of the BRAF gene that inhibits expression or results in the translation of either low-activity or inactive forms of the serine/threonine-protein kinase B-raf protein. 